\title{
Alkylphospholipids - A Promising Class of Chemotherapeutic Agents with a Broad Pharmacological Spectrum
}

\author{
Juliana de Almeida Pachioni, Juliana Gallottini Magalhães, Elys Juliane Cardoso Lima, Luciana de Moura Bueno, \\ Joyce Ferreira Barbosa, Matheus Malta de Sá, Carlota de Oliveira Rangel-Yagui
}

Department of Pharmacy, University of São Paulo, Avenida Prof. Lineu Prestes 580, Bl.13, São Paulo, SP, Brazil.

Received, August 15, 2013; Revised, October 24, 2013; Accepted, December 13, 2013; Published, December 16, 2013.

\begin{abstract}
PURPOSE: Since when alkylphospholipds (ALPs) were discovered and, even further after miltefosine's approval for the treatment of cutaneous metastasis of breast cancer and leishmaniasis, their activity against many other diseases have been extensively studied. This review aims to provide a summary of the alkylphospholipids' applications investigated so far. RESULTS: The mechanism of action of ALPs is not fully understood, however it is believed that they interfere with lipid homeostasis leading to cell apoptosis. Due to ALPs cytotoxic activity, this class of molecules has shown to be effective against many diseases and conditions. Besides the approval of miltefosine for application in cutaneous metastasis of breast cancer and visceral and cutaneous leishmaniasis, several other analogs have proved efficacy and are promising as less toxic alternatives. ALPs have also shown in vitro and in vivo activity against Trypanosoma spp., amoebae, Tricomonas vaginalis, Schistosoma mansoni, HIV, and some fungi and bacteria species. The use of ALPs for intraocular lens coating is also under investigation. In addition, a clinical trial comparing miltefosine with usual treatments to spontaneous urticaria is also being conducted. CONCLUSIONS: Alkylphospholipids present such a broad pharmacological spectrum that justifies the need for further investigations of the drug class mechanisms of action, as well as the search for new analogs with improved activity and toxicological profiles.
\end{abstract}

This article is open to POST-PUBLICATION REVIEW. Registered readers (see "For Readers") may comment by clicking on ABSTRACT on the issue's contents page.

\section{INTRODUCTION}

The use of synthetic metabolically stable analogs of lysophosphatidylcholines (LysoPC) as biological response modifiers is quite old (1). The idea of using lysophosphatidylcholine analogs for this purpose comes from the fact that LysoPC, an endogenous cell membrane component produced from the hydrolytic breakdown of phosphatidylcholines by phospholipases, acts as a modulator of several signaling pathways and some biochemical routes. In the late $60 \mathrm{~s}$, through the change of a glycerol $\mathrm{C} 1$ ester bond in Lyso PC to an ether bond, and the addition of other etherlinked methyl group at the $\mathrm{C} 2$ position, Hansjörg Eibl synthesized edelfosine (an ether lipid, 1-Ooctadecyl-2-O-methyl-rac-glycero-3-

phophocholine, Figure 1), the first molecule of this drug class known as ALPs (synthetic alkylphopholipids) (2). More recently, ALPs were divided into two groups: alkyl-lysophospholipids and alkylphospholipids (1).

Edelfosine was initially considered a very promising molecule owing to its immunomodulatory properties and inhibitory activity over tumor cell proliferation $(3,4)$. However, cytotoxicity assays carried out on a large variety of tumors (solid and hemathological, such as leukemia) and normal cell lines, showed that edelfosine is not highly selective for tumor cells $(5,6,7,8)$. Nonetheless, the molecule was also evaluated on its antiproliferative activity in vitro and in vivo (in murine models) and was proven to be effective $(6,9,10)$. However, edelfosine clinical use is limited mainly due to the molecule metabolic instability, high hemolytic potential and gastrointestinal toxicity. Edelfosine is used only for bone marrow purging in patients with acute leukemia $(11,12)$. New molecules have then been proposed and ilmofosine (1hexadecylthio-2-methoxymethyl-rac-glycero-3phosphocholine) was synthesized as a thio-ether analog.

Corresponding Author: Carlota de Oliveira Rangel-Yagui; Av. Prof. Lineu Prestes, 580 - Bloco 15; São Paulo, SP; E-mail: corangel@usp.br 
This chemical modification, however, did not alter significantly its metabolic stability or cytotoxic effect, preventing the clinical use of ilmofosine. Nonetheless, preliminary studies showed that this molecule is as an effective inhibitor of tumor cell proliferation $(3,4)$, encouraging the search for more stable analogs.

It was only in the late 80 s, with the discovery of a new analog lacking the glycerol motif, that ALPs reached a clinical important level. Miltefosine (hexadecylphosphocholine, HePC, Figure 1) was simultaneously synthesized by two different groups, one screening plateletaggregation analogs for anti-inflammatory purposes in the UK, and another searching for molecules with anti-tumor activity in Germany (13). Miltefosine became the prototype of a new class, called alkylphosphocholines (APCs), and led the way in the search for new molecules. Similarly to the earlier ALPs, miltefosine presented appreciable in vitro antiproliferative activity $(14,15)$. However, miltefosine was found to be highly hemolytic when administered parenterally and its oral application was associated with cumulative gastrointestinal toxicity (16). These severe side effects limited its maximum daily dose (MTD $=200 \mathrm{mg} /$ day), preventing in vivo observation of antiproliferative effects (17).

Another structural ALP modification aiming to improve the therapeutic potency refers to the replacement of the choline moiety of miltefosine by a heterocyclic piperidine group, resulting in perifosine (octadecyl-1-(1,1-dimethyl-piperidinio4-yl)-phosphate) (18). The insertion of the piperidine group increased stability and half-life by approximately 140 hours, preventing perifosine rapid metabolic degradation (19). This is actually an advantage over miltefosine, which is metabolized by phospholipases, yielding choline, phosphocholine and 1,2diacylphosphocholine (14). Despite the favorable pharmacokinetic profile and the in vitro cytotoxic effect of perifosine against a wide range of tumor cell lines (19), phase I clinical trials revealed a toxicological profile similar to miltefosine's, with a maximum tolerated dose of $200 \mathrm{mg}$ /day (17).

More recently, two other molecules, erucylphosphocholine (ErPC) and its homocholine analog erufosine (ErPC3) were developed, having in common a longer 22 carbon chain with a $\omega$-9-cis-double bond. This modification resulted in reduced hemolytic activity, thereby enabling intravenous administration, not feasible with previous ALPs
$(20,21)$. The reduction of the hemolytic potential can be explained by the fact that ErPC and ErPC3 form preferentially lamellar structures (less hemolytic) in aqueous solutions instead of micelles (1). Another very interesting feature of these new analogs refers to their ability to cross the blood-brain barrier. It has been demonstrated that ErPC is able to cross the blood-brain barrier and thus accumulates in the brain, reaching sufficient concentrations to kill human gioblastoma cell lines in vitro without observed severe toxic side effects (22). Moreover, studies with ErPC3 point to lower bone marrow toxicity when compared to other compounds of this class, allowing intravenous infusion at higher doses and, therefore, holding out possibilities for monotherapy or combination regimens (23). This fourth generation (ErPC and $\mathrm{ErPC} 3$ ) comprises the most promising ALPs up to date, and has been suggested as an interesting therapeutic option not only for cancer, but also for the treatment of several other diseases (1).

\section{Mechanisms of action}

Unlike other conventional anticancer agents, whose mechanisms of action are mainly based on interaction with the genetic machinery of the cell, it is proposed that the primary target of ALPs is the cellular membrane due to their similarity with endogenous phospholipids $(24,25)$. Structurally, they correspond to classical surfactants and may cause cell lysis at high concentrations. However, at clinical concentrations, ALPs insert into the lipid bilayer producing a biophysical disturbance of the cell membranes. The presence of micelles is important to the cell lysis mechanism, which involves micellar dissolution and partition into the membrane, phase transition between lamellae and micelles and decrease in the size of micelles (26), as shown in Figure 2. Micellar aggregation depends on the space occupied by the hydrophilic and hydrophobic groups of the surfactants (27). In general, it is accepted that the amount of surfactant required to solubilize a membrane increases with the ease of forming micelles, i.e., with the critical micellar concentration (CMC) (28).

There are few hypotheses to explain the activity of ALPs as shown in Figure 3. When metabolically stable ALPs insert into the membrane, they generate a biophysical perturbation, interfering with phospholipid metabolism, proliferation and cell survival signaling pathways, while simultaneously 


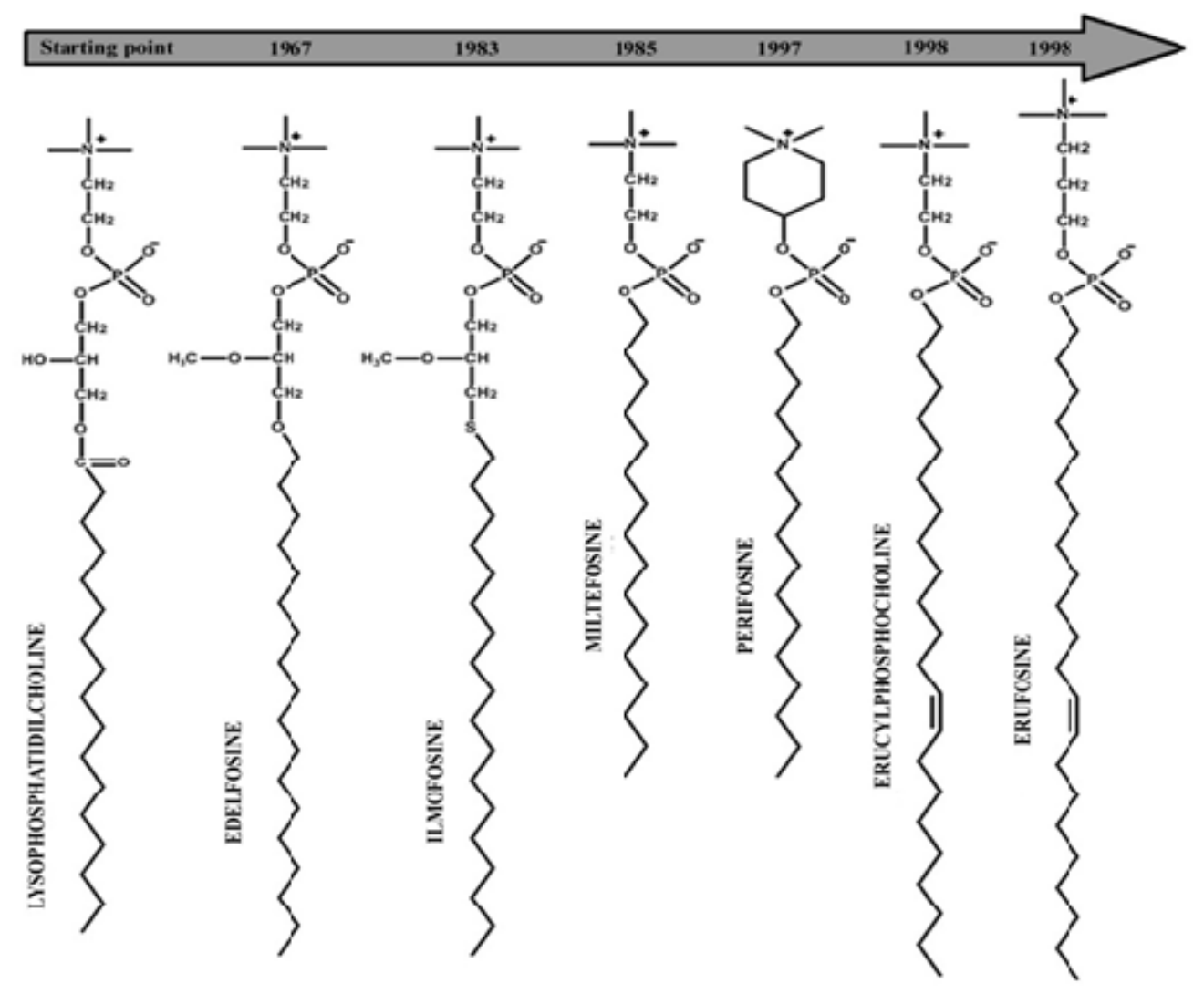

Figure 1. Timeline of alkylphospholipids development (Based on Blitterswijk and Verheij, 2012).

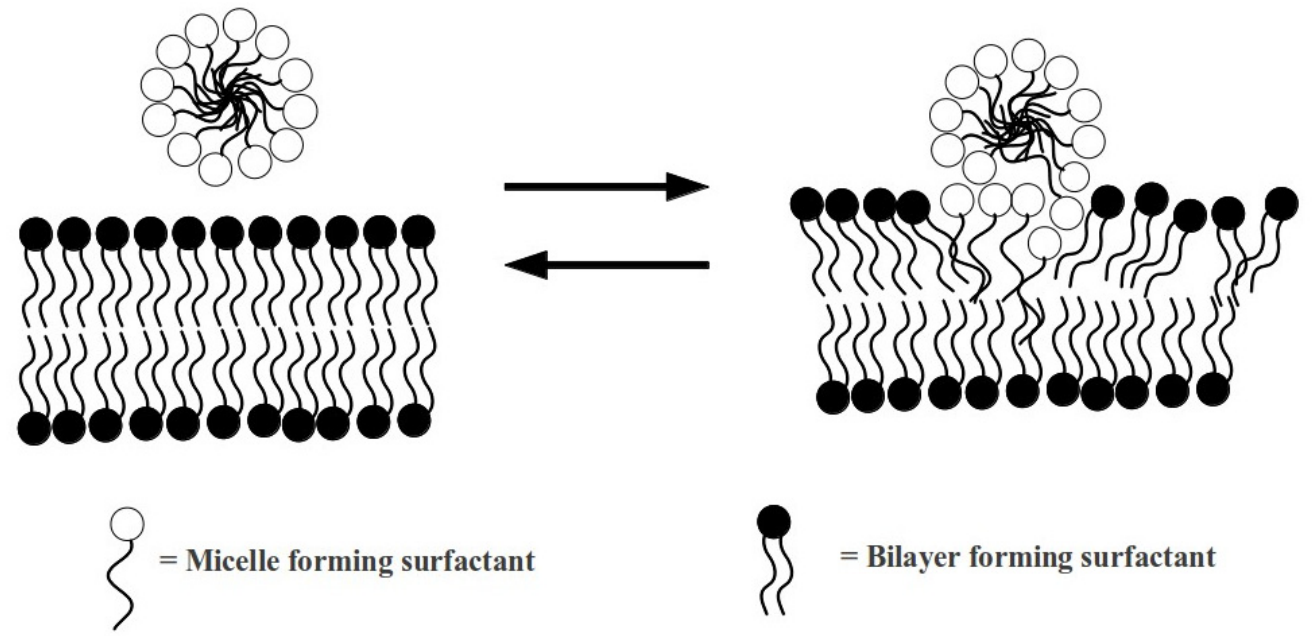

Figure 2. Schematic illustration of the micelle fusion and bilayer disruption process. The black and white circles represent the surfactant and phospholipids heads, respectively (hydrophilic moieties). The black curved lines represent the surfactant tails (hydrophobic moieties). 
activating several stress pathways that promote apoptosis (29). ALPs are easily inserted into the outer leaflet of the plasma membrane and pass through it with the help of a "flippase" ATPdependent complex. Another possible mechanism refers to an ALP endocytosis-based internalization by means of lipid rafts $(6,8,30$, 31).

The interference of ALPs with the metabolism of cell membranes leads to a cellular stress that, in turn, triggers apoptosis. The mechanism by which the inhibition of phosphocholine (PC) biosynthesis initiates apoptosis is not clear yet. It has been shown that the lack of PC in the endoplasmic reticulum somehow induces a stress of the pro-apoptotic transcription factor CHOP/GADD $153(32,33)$. It is well known that apoptosis can be triggered by a shift in the overall balance of apoptotic and survival signals. ALPs can also affect this balance via crosstalk between these pathways $(8,30,34)$. Not only do ALPs inhibit the PC biosynthesis, but can also, under certain signaling conditions, prevent its breakdown to phosphatidic acid and further degradation to diacylglycerol. The phosphatidic acid and diacylglycerol are second messengers involved in the mitogen activated protein kinase (MAPK) and Ras/Raf/MEK/ERK signaling pathways, which are involved in cell proliferation $(8,30,34,35)$.

Besides the self-accumulation in membrane microdomains (lipid rafts), ALPs can also affect cholesterol homeostasis and promote lipid rafts perturbations, what would increase its uptake and lead to apoptotic signaling $(36,31,37)$. ALPs inhibit the cholesterol transport from the cellular membrane to endoplasmic reticulum and, thereby, prevent its esterification. This leads to an accumulation of free cholesterol in cell membrane lipid rafts, which may affect signaling processes that are vital to cells survival and growth $(38,39$, 1).

The best ALPs characterized target is the AKT enzyme, a serine/threonine kinase which is a key regulator of various cell survival pathways $(40,41,42,43)$. AKT is activated in most human cancers and contributes to cell growth, proliferation and cellular survival pathways, being an attractive target for anticancer therapy (44). ALPs prevents AKT activation either by disrupting membrane microdomains that are crucial to growth factor signaling, or by displacing the natural AKT ligands, PIP2 (phosphatidylinositol-4,5-biphosphate) and PIP3 (phosphatidylinositol- 3,4,5-triphosphate) (42, 45, 46).

As a result, AKT is no longer capable of adopting the favorable conformation for its phosphorylation and activation (47, 48). Perifosine, in particular, is known to target the lipid-binding pleckstrin homology $(\mathrm{PH})$ domain of AKT and to inhibit its translocation to cell membrane, an essential step for the enzyme activation (49). Studies about induced stress and pro-apoptotic pathway interference mechanisms have indicated that edelfosine can also promote the endoplasmic reticulum stress and generate ROS (reactive oxygen species), leading to ASK1 (apoptosis signal-regulating kinase 1) activation and apoptosis induction (32, $50,51,52)$.

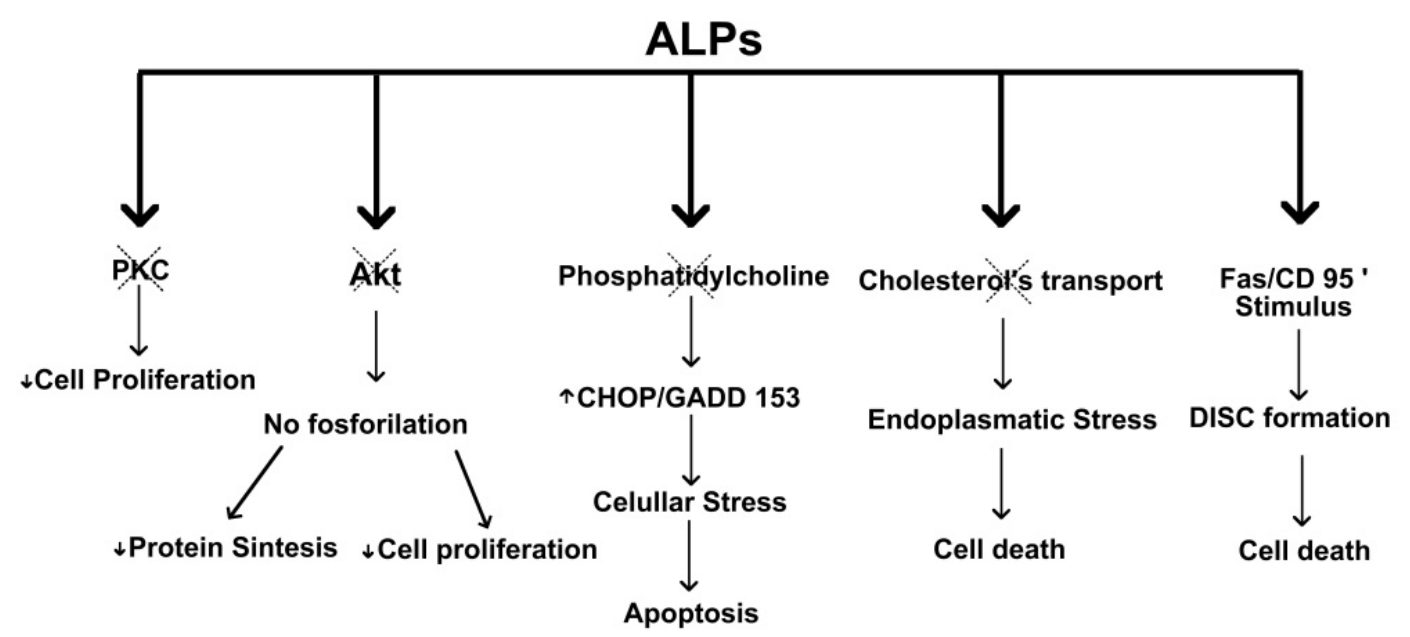

Figure 3. Schematic representation of the hypotheses for ALPs mechanism of action. 
ASK1 plays a crucial role on an apoptotic signaling pathway activated in response to some types of stress, such as ROS, tumoral necrosis factor (TNF- $\alpha$ ), and endoplasmic reticulum stress $(53,54)$.

Another possible mechanism is the stimulation of Fas/CD95 that induces apoptosis by promoting the formation of a complex named DISC (death inducing signaling complex) (55, 56). The DISC formation and resulting apoptosis are based on Fas redistribution in lipid rafts (56, 57). Mollinedo et al. has shown that ALPs can induce Fas redistribution in lipid rafts at certain lymphoid tumoral cells, independently of endogenous ligands. This theory is strongly supported by the fact that treatment with methyl$\beta$-ciclodextrine (a cholesterol remover from cell membranes) caused lipid raft rupture and prevented Fas redistribution induced by ALPs $(58,59,60)$.

A mechanism related to PKC (protein kinase C) inhibition is also described, although this may not be the main mechanism leading to apoptosis (61). Owing to the similarity between ALPs and the endogenous substrates of PKC, namely PS (phosphatidyl serine) and PIP2 (phosphatidylinositol-4,5-biphosphate), it is proposed that ALPs can inhibit PKC by interacting with the regulatory domain $\mathrm{C} 2$, whereas the regulatory domain $\mathrm{C} 1$ recognizes the endogenous compound diacylglicerol (DAG) and phorbol esters. The inhibition, or regulation, of any of these domains modulates the phosphorylation of endogenous proteins, and can prevent cell growth by interfering with signaling pathways $(62,63,64,65)$.

\section{Resistance mechanisms}

Resistance to ALPs usually involves one of the two mechanisms of internalization described for this class. One refers to the trans-bilayer movement from the outer to the inner leaflet of the cell membrane that usually involves an ATPdependent lipid translocator/flippase. The other mechanism corresponds to the internalization by endocytosis. The resistance against ALPs in squamous cell carcinoma and in RAW cells 264.7 (mouse leukemic monocyte macrophage cell line) is related to a dysfunctional flippase and a higher expression of Bcl-2 (B-cell lymphoma 2) antiapoptotic protein. Without a functional flippase, ALPs are not significantly internalized into the cell and, consequently, cannot act on molecular pathways leading to apoptosis $(66,67)$. According to recent studies, resistant lymphoma rat cells S49 and S49AR that does not show ALPs internalization, have lower expression of Fas/CD95 and greater ERK/AKT signaling (31, $68,69)$. S49AR cells also lack sphingomyelin, one of the main constituents of lipid bilayers, as cholesterol, due to a lower expression of sphingomyelin synthase (SMS1). Sphingomyelin is essential for lipid synthesis and for the cell membrane vesicular traffic. Without sphingomyelin, ALPs cannot not form lipid rafts and, therefore, be internalized by endocytosis (69).

\section{CLINICAL APPLICATIONS \\ Cancer}

The first synthetic alkylphopholipid, edelfosine, had its use restricted to bone marrow purging in acute leukemia patients due to its high toxicity and lack of selectivity $(11,12)$. Nonetheless, studies with this molecule were resumed in 2010 when Molinedo et al. showed that, in an in vitro trial, in which edelfosine was able to induce apoptosis in mantle lymphoma and chronic lymphocytic leukemia cells via lipid raft with greater efficiency than other ALPs (7). The thioether analog of edelfosine, ilmofosine, has also showed anti-tumoral in vivo activity in preclinical trials, reaching phases I and II. Despite the primary promising results, phase I clinical trials of ilmofosine limited its maximum dose for both oral and intravenous administration mainly due to gastrointestinal toxicity $(70,71)$, and phase II trial ended up finding no objective results (72, 73).

Clinical studies were also carried out to evaluate the activity of miltefosine against soft tissue sarcoma (16), metastatic colorectal cancer (74), and head and neck squamous cell carcinoma (16). However, these studies were ceased in phase II trial since the oral doses required for the systemic effect were toxic to the gastrointestinal tract. For this reason, since its approval as Miltex ${ }^{\circledR}$ in 1992 in Germany, the clinical use of miltefosine is limited to the topical treatment of breast cancer cutaneous metastasis. The oral application of miltefosine is approved in some countries for treatment of visceral and cutaneous leishmaniasis (75) and the drug is currently under investigation for other diseases, such as some parasitosis.

In addition, phase II clinical trials with perifosine (table1) as a single agent for the treatment of advanced or metastatic breast cancer, head and neck cancer, soft tissue sarcomas, metastatic melanoma, prostate cancer, and 
adenocarcionoma were disappointing $(1,14,15$, $71,73,76,77)$. In spite of that, several studies with this drug as an anticancer agent in association with other drugs showed that such therapeutic approach can result in numerous clinical benefits. Perifosine can increase the antineoplastic effect of other drugs on tumor cells, producing better results. The combined therapy of perifosine with different agents, such as lenalidomide (thalidomide analog) and dexamethasone, is currently in phase I study for multiple myeloma and good results have been observed so far (78). In a more advanced phase II trial, perifosine was used in combination with bortezomib, a reversible proteasome inhibitor, in association or not with dexamethasone, to treat multiple myeloma; results are also promising. Perifosine has been given Fast Track status by the FDA for this indication and is currently in phase III clinical trials (23). The best results have been observed when perifosine is combined with temsirolimus, an mTOR inhibitor, to treat patients with neuroblastoma. Based on preclinical data and the premise that direct AKT inhibition may overcome AKT activation secondary to mTOR inhibition, perifosine-temsirolimus combined therapy shows a synergistic effect and have been considered very promising (49).

As well as perifosine, the fourth generation of ALPs, currently represented by erucylphosphocholine and erufosine, has been highlighted on in vitro and pre-clinical assays (Table 1), which can indicate a new perspective in cancer treatment. Rübel et al studied the in vitro putative beneficial effects of ErPC and ErPC3 in combination with radiation on human astrocytoma and glioblastoma cell lines (T98G, A172 and U87MG). The combined treatment enhanced the induced damage to mitochondria and caspase-activation, besides increasing the radiation-induced eradication of clonogenic $\mathrm{T} 98 \mathrm{G}$ cells (79). Other studies have tested ErPC and ErPC3 against choriocarcionoma, acute myeloid leukemia, chronic lymphocytic leukemia and oral squamous cell carcinoma (Table 1).

\begin{tabular}{|c|c|c|}
\hline Type of Cancer & Perifosine & References \\
\hline Relapsed and refractory multiple myeloma & Phase III & Aeterna Zentaris, $2013(80)$ \\
\hline $\begin{array}{c}\text { Taxane and platinum-resistant or refractory epithelial } \\
\text { ovarian cancer }\end{array}$ & Phase I & Fu S et al, 2012 (81) \\
\hline Advanced renal cell carcinoma & Phase II & Cho D C et al, 2012 (82) \\
\hline Metastatic colorectal cancer & Phase II & Bendell J C et al, 2011 (83) \\
\hline $\begin{array}{l}\text { Relapsed and refractory and Waldenstrom's } \\
\text { macroglobulinemia }\end{array}$ & Phase II & Ghobrial I M et al, 2010 (84) \\
\hline Solid tumors & Phase I & Unger C et al, 2010 (85) \\
\hline Recurrent prostate cancer & Phase II & Chee K G et al, 2007 (86) \\
\hline Metastatic pancreatic adenocarcinoma & Phase II & Marsh R W et al, 2007 (87) \\
\hline Head and neck cancer & Phase II & Argiris A et al, 2006 (88) \\
\hline Advanced soft tissue sarcoma & Phase II & Bailey H H et al, 2006 (89) \\
\hline Metastatic melanoma & Phase II & Ernst D S et al, 2005 (90) \\
\hline Androgen independent prostate cancer & Phase II & Posadas E M et al, 2005 (91) \\
\hline \multicolumn{3}{|c|}{ Erucylphophocholine } \\
\hline Choriocarcionoma & in vitro & Takai N et al, 2011 (92) \\
\hline $\begin{array}{l}\text { Breast carcinoma, pancreatic carcinoma and multiple } \\
\text { myeloma }\end{array}$ & in vitro & Bagley R G et al, 2011 (23) \\
\hline Prostate cancer & in vitro & Rudner J et al, 2010 (93) \\
\hline Endometrial and ovarian cancer & in vitro & Takai N et al, 2008 (94) \\
\hline Astrocytoma and glioblastoma & in vitro & Rübel A et al., 2006 (79) \\
\hline \multicolumn{3}{|c|}{ Erufosine } \\
\hline Breast cancer & Pre-clinical & Dineva I K et al, 2012 (35) \\
\hline Oral squamous cell carcinoma & in vitro & Kapoor V., 2012 (95) \\
\hline Multiple myeloma & in vitro & Yosifiv D Y et al, 2011 (96) \\
\hline Multiple myeloma & in vitro & Königs S K et al, 2011 (97) \\
\hline Acute myoloid leukemia & in vitro & Fiegl M et al., 2007 (24) \\
\hline Astrocytoma and glioblastoma & in vitro & Rübel A et al., 2006 (79) \\
\hline Breast carcinoma and leukemia & in vitro & Berger M R et al, 2003 (98) \\
\hline
\end{tabular}




\section{Leishmaniasis}

The activity against Leishmania protozoan was first described by Croft et al., who found out that miltefosine was able to inhibit $100 \%$ of Leishmania donovani infection in mice, on a dose of $100 \mathrm{mg} / \mathrm{kg} /$ day (99). An oral presentation of miltefosine, Impavido ${ }$, is registered since early 2000 for the treatment of visceral leishmaniasis in Nepal and also for the cutaneous form of the disease in other countries such as Argentina, Bangladesh, Bolivia, Colombia, Ecuador, Germany, Guatemala, Honduras, India, Mexico, Pakistan, Paraguay and Peru (75). In India, there is also a generic miltefosine product available for the treatment of the visceral form of the disease (13). Miltefosine is the only oral drug available for the treatment of leishmaniasis so far. The World Health Organization (WHO) does not recommend miltefosine as first choice for the treatment of any type of leishmaniasis in any region, giving preference to pentavalent antimony and liposomal amphotericin B, alone and in association (100). Nonetheless, miltefosine monotherapy has been suggested as first-line choice for the treatment of visceral leishmaniasis at the Bihar district, in India (101).

Miltefosine is efficient against antimony resistant Leishmania, yet, its effectiveness is different for each protozoan species and each geographic location. Escobar et al. showed that miltefosine sensitivity was greater for intracellular amastigotes of $L$. donovani $\left(\mathrm{ED}_{50}\right.$ of 3.32- $4.56 \mu \mathrm{M}$ ), followed by $L$. aethiopica, $L$. tropica, $L$. mexicana, and $L$. panamensis. The $L$. major amastigote was significantly less sensible $\left(\mathrm{ED}_{50}\right.$ of $\left.31.56-37.17 \mu \mathrm{M}\right)$ (102). Another in vitro study also showed a different profile of sensitivity of amastigotes among the species of $L$. donovani $\left(\mathrm{ED}_{50}=8.7-0.04 \mu \mathrm{g} / \mathrm{mL}\right), \quad L$. braziliensis $\left(\mathrm{ED}_{50}=>30-8.4 \mu \mathrm{g} / \mathrm{mL}\right), L$. guyanensis $\left(\mathrm{ED}_{50}=>30-1.9 \mu \mathrm{g} / \mathrm{mL}\right), L$. mexicana $\left(\mathrm{ED}_{50}=30 \mu \mathrm{g} / \mathrm{mL}\right)$ and $L$. lainsoni $\left(\mathrm{ED}_{50}=3.4-1.9 \mu \mathrm{g} / \mathrm{mL}\right)$ (103). Data from clinical trials of different countries also suggested that different isolates from the same species have variable responses to miltefosine. While a clinical trial carried out in Bolivia presented $88 \%$ cure rate of cutaneous leishmaniasis caused by $L$. braziliensis (104), another performed in Guatemala, where L. braziliensis is also the most common form, resulted in 53\% cure rate (105).

The best perspective for miltefosine as an effective treatment for both visceral and cutaneous leishmaniasis consists on its association with other drugs (13). Some clinical trials have been made in the last decade with different associations in a search for more efficient, tolerable, shorter and cheaper treatments for visceral leishmaniasis. A phase III clinical trial performed in India concluded that all combination therapies tested (single dose liposomal amphotericin B followed by miltefosine or paromomycin, and 10 days miltefosine followed by 10 days paromomycin) had similar or higher cure rates and were more tolerable than the standard first choice treatment with amphotericin B alone (106).

Although clinical trials for leishmaniasis with other ALPs have not been conducted so far, there are evidences of their antiparasitic activity. Escobar et al. have shown that intracellular amastigotes were more sensitive to edelfosine compared to miltefosine (102). A more recent study compared the activity of four ALPs and concluded that edelfosine was the most active against different leishmania species, followed by perifosine, miltefosine and erucylphosphocholine. Edelfosine also proved to be an efficient alternative against antimonial resistant strains (107). The activity of perifosine has also been demonstrated in vitro against $L$. braziliensis, $L$. infantum, L. major and L. amazonensis strains (108). In a subsequent study on mice with cutaneous leishmaniasis caused by $L$. amazonensis, perifosine presented a higher degree of lesions reduction in comparison to miltefosine (109).

Miltefosine has also been successfully used for the treatment of visceral leshimaniasis on individuals co-infected with human immunodeficiency virus type-1 (HIV-1) (110, 111). Interestingly, several studies have shown that miltefosine exerts significant immunomodulatory properties in different cell types, being also a promising drug against HIV $(112,113)$. A recent study performed by Garg and Tremblay showed that miltefosine was able to reduce HIV-1 replication inside $\mathrm{CD} 4(+) \mathrm{T}$ cells partially due to secretion of type I Interferon by dendritic cells (114). Other study proved that miltefosine combined with sodium nitroprusside (SNP), which generates cytotoxic nitric oxide, reduces HIV-1 replication in macrophages, via downstream activation of AKT kinase. The same effect was observed with perifosine (115). These studies show that miltefosine, in addition to its anti-leishmanial property, can also prevent the spread of HIV-1. Hence, the in vitro inhibitory activity of miltefosine against HIV-1 and its efficacy on other cellular targets (eg, 
macrophages) are important to validate its use on a larger scale on individuals co-infected with HIV-1 and Leishmania spp. The clinical relevance of these studies, however, remains to be determined (114).

\section{Chagas disease and sleeping sickness}

It is reasonable that drugs that are effective against leishmaniasis may also be useful against Chagas disease and sleeping sickness, given the fact that Leishmania spp. and Trypanosoma spp. are parasites of the Kinetoplastid order (116, 117). The ALP's action against Trypanosoma spp. has been investigated since 1996, when Croft et al. described that Trypanosoma cruzi was more sensitive to miltefosine, ilmofosine and edelfosine, with $\mathrm{ED}_{50}$ of $0.5 \mu \mathrm{M}, 0.2 \mu \mathrm{M}$ and 1.4 $\mu \mathrm{M}$ respectively, than to nifurtimox, with $\mathrm{ED}_{50}$ of $2.7 \mu \mathrm{M}$ (118).

Miltefosine is the most studied ALP against both $T$. cruzi and $T$. brucei species, probably because it is already approved for leshmaniasis. Various in vitro and in vivo studies have demonstrated that this drug is more active against T. cruzi than the standard drugs, nifurtimox and benznidazole $(119,120)$. Saraiva et al. showed that miltefosine produced higher reduction on the parasitemia level than benznidazol in mice with acute Chagas disease (119). Although alkylphosphocholines were less active against $T$. brucei than $T$. cruzi (118), miltefosine on a dose of $30 \mathrm{mg} / \mathrm{kg} /$ day was able to increase the lifetime of mice infected by T. brucei by $35 \%$. In addition, the effect of the drug seems to vary according to the protozoan subspecies, being greater against $T$. b. brucei, followed by T. b. rhodesiense and T. $b$. gambiense (121). Although other ALPs such as edelfosine and ilmofosine were less studied for antitrypanosomal activity, they also present activity against this protozoan, but not as powerful as miltefosine (122).

Despite the great action of miltefosine against T. cruzi and T. brucei, its use is still restricted due to gastrointestinal toxicity and hemolytic effect observed with the required dose for therapeutic effect. Therefore, no clinical trials for ALPs involving Chagas disease or sleeping sickness have been conducted so far. Some studies considered drug association therapies, allowing the administration of lower doses of miltefosine and, as a result, lower incidence of side effects (121, 123). Santa-Rita et al. observed better results in terms of $T$. cruzi lysis with an association of ketoconazole and one ALP (miltefosine, edelfosine or ilmofosine), in comparison with the isolated drugs. This result can be explained as a synergistic effect of the drugs inhibiting the protozoan's phospholipid metabolism (123).

\section{Other parasitosis}

The great effect of alkylphosphocholines against Leishmania and Trypanossoma gave rise to new research on these molecules into others parasitosis. In 2001, the activity of this class against amoebae was first described by Seifert et $a l$. The authors showed that miltefosine and other ALPs analogs were able to kill Entamoeba histolytica, with the best results corresponding to an oleyl-PC derivative presenting an $\mathrm{EC}_{50}$ for SFL-3 strain of $15 \mu \mathrm{M}$ after two days of treatment. Miltefosine was the least effective among all analogs tested, with $\mathrm{EC}_{50}$ between 57 and $225 \mu \mathrm{M}$ (124). However, on another study performed with different clinical isolates of Acanthamoeba spp., miltefosine proved to be the most effective ALP, corresponding to a maximum $\log$ reduction of $100 \%$ at $40 \mu \mathrm{M}$. These results have enabled future investigations of ALPs for the treatment of Acanthamoeba keratitis and granulomatous amoebic encephalitis (125).

Another potentiality of ALPs already demonstrated refers to the treatment of Trichomonas vaginalis, an anaerobic flagellate protozoan. This application was first described in 2002 by Blaha et al., who investigated miltefosine activity against four strains of $T$. vaginalis, two metronidazole-resistant and two metronidazolesusceptible. The results showed that $T$. vaginalis susceptibility to miltefosine is not straindependent and does not correlate well with metronidazole susceptibility, which can be understood based on their different mechanisms of action. While metronidazole is activated in the hydrogenosomes of the organisms, resulting in a nitro radical damage to the genomic DNA and inhibiting cell division, miltefosine interacts with the cell membrane resulting in cell lysis. More specifically, miltefosine resulted in rounding up, immobility, blebbing and total lysis of the organisms. Blebbing of the cell membrane has also been observed in Entamoeba and Acanthamoeba treated with miltefosine and may reinforce an apoptotic mechanism. An important observation of this study is that no effect was recorded after incubation times $<30 \mathrm{~min}$, indicating that the cytotoxic effect of miltefosine on $T$. vaginalis is not immediate. This is reinforced by the lower values of $\mathrm{EC}_{50}$ and $\mathrm{EC}_{90}$ after longer incubation times. A time dependent 
cytotoxic effect of miltefosine had already been found in E. histolytica and is also consistent with the proposed mode of action of this drug (126).

Several studies also support the use of miltefosine for the treatment of Schistosomiasis. The hypothesis that this drug can act against Schistosoma mansoni is mainly related to the fact that this parasite presents an uncommon lipid bilayer, which is important for the host-parasite relationship (127). Miltefosine presents a lipophilic alkyl chain that enables the molecule to penetrate into the parasite lipid bilayer and a polar quaternary nitrogen which facilitates the transport through an aquaporin (SmAQP) (128). In addition, the choline portion of miltefosine structurally resembles metrifonate, an irreversible organophosphate acetylcholinesterase inhibitor that used to be employed against Schistosoma mansoni (129). Miltefosine on an oral daily dose of $20 \mathrm{mg} / \mathrm{kg}$ on a five-day treatment of Schistosoma mansoni infected mouse showed to be more efficient than praziquantel, resulting in significant parasite load reduction and hepatic pathology improvement. Electronic microscopy analysis also revealed severe damage on adult Schistosoma tegument after miltefosine treatment (130).

\section{Fungi infection}

In 2006, Widmer et al. tested miltefosine against some fungi species and significant activity was observed against Scedosporium prolificans, an infectious agent with few effective therapeutic alternatives (131). In the same work, it was suggested that the treatment of Cryptococcus spp. with miltefosine might cause inhibition of LPTA (lysophospholipase-transacylase), an enzyme involved in membrane synthesis, in a concentration dependent manner. It has also been reported an inhibitory activity of PLB1, phospholipase $\mathrm{B}$, which is responsible for hematogenic spread and for the fungus adhesion to mammalian cells $(132,133)$. The antifungal activity of a series of ALPs analogs against Cryptococcus neoformans and Candida albicans has also been demonstrated and it was shown to correlate with the alkyl chain size, with the 18 carbons analog being more active than miltefosine (134).

Regarding the activity against Candida albicans, a work by Lukáč et al. compared miltefosine to Isophol-PC analogs (ALPs with branched alkyl chains), and a MIC of 5 to $20 \mu \mathrm{M}$ was observed for miltefosine, while the compounds Isophol ${ }_{16}$-PC and Isophol $20-\mathrm{PC}$ showed MIC values between 40 and $150 \mu \mathrm{M}$. In another work, the same authors compared APCs and quaternary ammonium analogs and demonstrated that miltefosine was among the most active compounds, although all analogs studied presented relevant activity (135). In a recent work, the ability of miltefosine to inhibit Candida albicans biofilm formation was demonstrated (136).

The in vitro activity of miltefosine was also tested against nine species of dermatophytic fungi (T. rubrum, T. mentagrophytes, T. tonsurans, $T$. soudanense, $T$. violaceum, E. floccosum, M. canis, M. gypseum and M. cookei) and it was shown to be up to four times more active than itraconazole, a drug used for the treatment of chronic and severe infections caused by Trichophyton spp. and Microsporum spp. (137).

\section{Bacterial infection}

The activity of alkylphosphocholines and alkylglycerophosphocholines against fungi and protozoa had encouraged the research for their antibacterial activity (134).

Miltefosine was proved to be active against Streptococcus spp., but the activity significantly varied among species. For Streptococcus pneumoniae, MIC values ranging from 5 to 6.25 $\mathrm{mM}$ were observed, while for other streptococci (S. mitis, S. oralis, S. pyogenes, S. agalactiae, $S$. mutans) MIC values ranged from 10 to $20 \mu \mathrm{M}$. There is evidence that miltefosine's action against these bacteria is primarily related to its surfactant properties, which enable the solubilization of lipoteichoic acid present in the pneumococcal membrane and a natural inhibitor of autolysin LytA, an enzyme responsible for the degradation of the cell wall peptidoglycan $(138,139,140)$.

In a study performed by Huelves et al. (2008), miltefosine activity against pneumococcal strains was tested both in vitro and in vivo. Miltefosine showed in vitro effect, however, according to the authors, MICs varied in a disparate manner under the influence of different culture media. One can infer that, giving the amphiphilic nature of miltefosine, it may have interacted with several constituents of culture media, interfering with the results. In the in vivo test, the drug was not effective (141).

In 2012, Lukáč et al. investigated the activity of miltefosine and other alkylphosphocholines with branched chains (Isophol-PC) against not only fungi, as mentioned before, but also Staphylococcus aureus and Escherichia coli. Among the compounds tested, Isophol ${ }_{16}-\mathrm{PC}$ and 
Isophol $_{20}$-PC showed relevant activity against $S$. aureus, corresponding to MIC of $0.15 \mathrm{mM}$ and $0.31 \mathrm{mM}$, respectively. Miltefosine, on the contrary, did not present significant activity against $S$. aureus (135). Despite the results obtained by Lukáč et al., previous studies by Obando et al. revealed a MIC of miltefosine against $S$. aureus isolate of $44 \mu \mathrm{M}$. The same study also showed ALPs activity against two clinically significant gram-positive bacteria: methicillin-resistant $S$. aureus (MRSA) and vancomycin resistant Enterecoccus (VRE). The authors present a MIC of $44 \mu \mathrm{M}$ for miltefosine against VRE and $22 \mu \mathrm{M}$ against MRSA (134). It is clear, therefore, that new studies are needed in order to prove the effectiveness of ALPs against these strains.

It is also worth to mention that ALPs did not affect the growth of the gram-negative bacteria Escherichia coli and Pseudomonas aeruginosa, indicating that the outer membrane barrier prevents the drug from reaching the cytoplasmic membrane of these organisms $(134,140)$.

\section{Other applications}

\section{Intraocular lens coating}

ALPs have also been investigated for other nonchemotherapeutically related applications, such as coating agent for intraocular lens. Previous studies considered the possibility of using coated intraocular lens as a polymeric drug-delivery device. A good coating agent should be able to inhibit epithelial cell growth over the lens, since posterior capsule opacification (PCO) is caused by cell proliferation, migration and attachment in the capsular bag (142). In this sense, ALPs would be appropriate coating agents of foldable hydrophilic acrylic intraocular lens to be used in cataract surgery (143). It was shown that ALPs in concentrations in the range of $1 \mathrm{mM}$ are not only well tolerated by human corneal endothelial cells but also capable of reducing human ocular cell proliferation. Clearly, more investigation is still necessary to ensure biocompatibility and physicochemical properties of ALPs as coating agents, but there is a good potential for this novel application (143).

\section{Chronic spontaneous urticaria}

The first evidence that miltefosine could be used for chronic spontaneous urticaria was reported by Grosman, who described inhibition of histamine release from rat mast cells (144). Weller et al., in 2009, demonstrated that processes mediated by signal transduction receptors, such as those involved in immunoglobulin E (IgE) - receptor (FceRI) mast cell-dependent activation with subsequent degranulation, are regulated by lipid rafts in the cell membrane (145). The same study also showed that miltefosine can inhibit the activation of degranulation and inflammatory mediator release by human mast cells in vitro, being able to avoid inflammatory reactions mediated by these cells. In addition, a previous study has shown that miltefosine causes inhibition of signal transduction pathways at cell membrane level (146). These observations support the theory that miltefosine acts as a lipid raft modulator and, thereby, interferes with the response of mast cell activation and degranulation (147). All these findings justify further investigations of miltefosine and other ALPs to treat other inflammatory disease than cancer, such as allergies.

Magerl et al. performed a randomized, double-blind, placebo-controlled multicentre study and found that miltefosine was as effective as antihistamines in preventing urticaria symptoms when compared to placebo, in a 4week treatment period. Miltefosine is usually well tolerated and safe for systemic use in the required dosage for the treatment of urticaria, despite some adverse events as abdominal discomfort, nausea and vomiting. Therefore, miltefosine seems to be an interesting treatment option for chronic spontaneous urticaria patients who do not respond to standard-dosed antihistamines (147).

\section{Ongoing and anticipated research}

Considering the potential of alkylphospholipids as chemotherapeutic agents, as well as the new applications under investigation (Figure 4) such as intraocular lens coating, our group has been carrying out research on this topic, with special attention to the synthesis of molecules with lower hemolytic potential $(148,149)$. Moreover, we investigated the physical-chemical and structural characteristics of ALPs that most influence the hemolysis (150). Regarding amphiphilic compounds, it is noteworthy to mention that hemolysis occurs through mechanisms involving surfactant-membrane interaction and membrane disruption/solubilization. The presence of micelles is important in this mechanism, which involves micellar dissolution and partition into membrane, phase transition between lamellae and micelles and decrease in the size of micelles (26). It is generally accepted that the amount of surfactant required to solubilize a membrane increases with 
the ease of forming micelles, expressed by the critical micellar concentration (CMC) (28). Therefore, our group focuses on developing molecules that will preserve the minimum requirements for chemotherapeutic activity but present higher $\mathrm{CMC}$ values, i.e., that will be more difficult to aggregate into micelles. Additionally, we are also carrying out coarse-grained molecular dynamics simulations to investigate the interaction and partition of monomers in different lipid bilayers, as well as the changes in the membrane caused by monomers and micelles insertion. Developing a molecular understanding of the mechanisms mentioned above is extremely relevant for the future design and development of ALPs-based drugs.

The unique mechanism of action of ALPs on cellular membranes and their interference with the lipid metabolism and rafts, apart from their action on enzymes responsible for the cellular signaling, give this class an advantage over the currently used chemotherapeutic agents. Apart from it, ALPs can be synergistically combined with other chemotherapeutic drugs so as to overcome pathogens mechanisms of resistance. The many therapeutic applications show the potentials of this class and thus the development of a molecular understanding of the mechanisms mentioned above is extremely relevant for the future design and development of ALPs-based drugs.

\section{DECLARATIONS}

\section{Conflict of interest}

The Author(s) declare(s) that they have no conflicts of interest to disclose.

\section{Funding}

We acknowledge the grants and fellowships from the Coordination for Higher Level Graduate Improvements (CAPES/Brazil), National Council for Scientific and Technological Development (CNPq/Brazil) and State of São Paulo Research Foundation (FAPESP/Brazil, Proc. No 2011/02189-8).

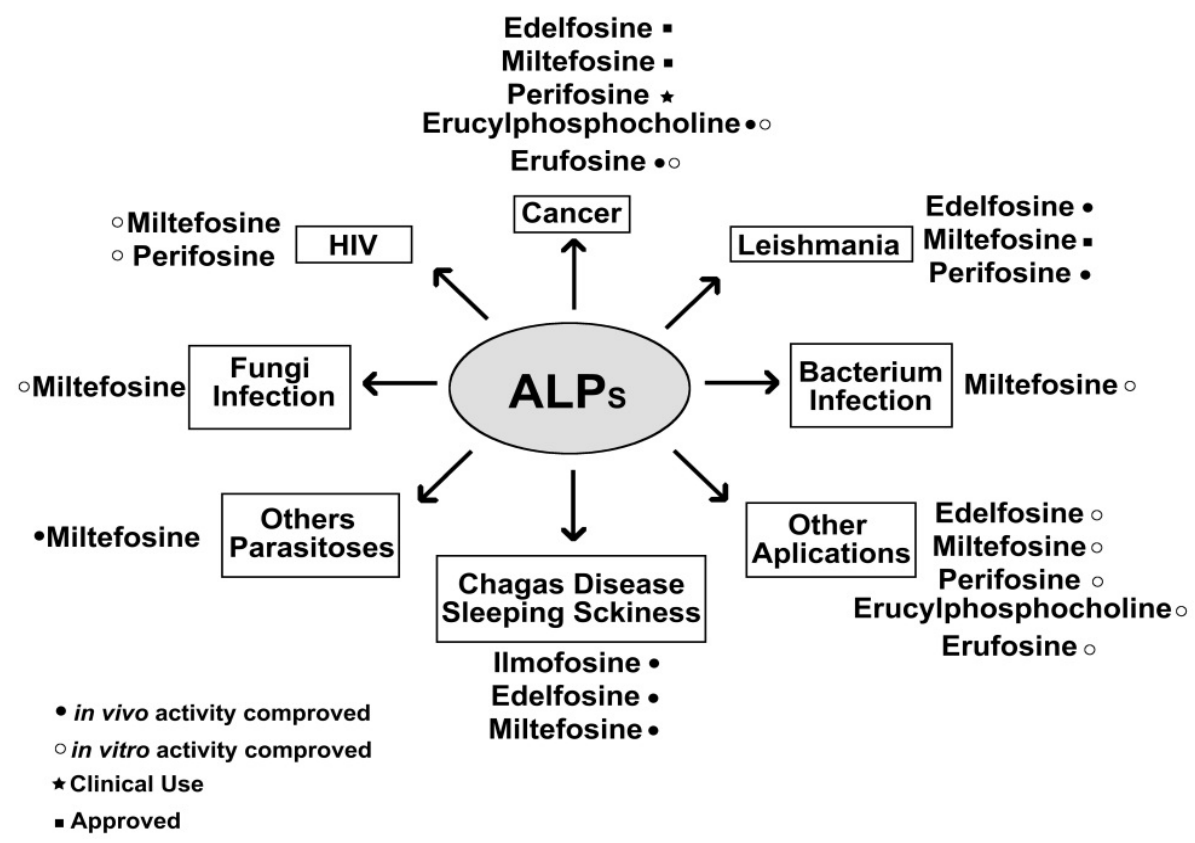

Figure 4. Alkylphospholipid's applications. 


\section{REFERENCES}

1. van Blitterswijk WJ, Verheij M. Anticancer mechanisms and clinical application of alkylphospholipids. Biochim Biophys Acta, 2012; 1831(8): 663- 674.

2. Eibl RH, Arnold D, Weltzien HU, Westphal O. On the synthesis of alpha beta lecithins and their analogs. Justus Liebigs Ann Chem, 1967; 704: 226-230.

3. Andreesen R, Modolell M, Weltzien HU, Eibl $\mathrm{H}$, Common HH, Löhr GW et al. Selective destruction of human leukemic cells by alkyllysophospholipids. Cancer Res, 1978; 38: $3894-$ 3899.

4. Munder PG, Modolell M, Andreesen R, Weltzien HU, Westphal O. Lysophosphatidylcholine (lysolecthin) and its synthetic analogues. Immunomodulating and other biologic effects. Springer Seminars in Immunopathology, 1979; 2: 187-203.

5. Runge MH, Andreesen R, Pfleiderer A, Munder PG. Destruction of human solid tumors by alkyl lysophospholipids. J Natl Cancer Inst,1980; 64(6): 1301-1306.

6. Mollinedo F, Fernández-Luna JL, Gajate C, Martín-Martín B, Benito A, Martínez-Dalmau R et al. Selective induction of apoptosis in cancer cells by the ether lipid ET-18-OCH3 (Edelfosine): Molecular structure requirements, cellular uptake, and protection by Bcl-2 and BclX(L). Cancer Res, 1997; 57(7): 1320-1328.

7. Mollinedo F, de la Iglesia-Vicente J, Gajate C, Estella-Hermoso de Mendoza A, VillaPulgarin JA, de Frias M, et al. In vitro and in vivo selective antitumor activity of Edelfosine against mantle cell lymphoma and chronic lymphocytic leucemia involving lipids rafts. Clin. Cancer Res, 16 (2010) 2046-2054.

8. Ruiter GA, Zerp SF, Bartelink H, van Blitterswijk WJ, Verheij M. Alkyllysophospholipids activate the SAPK/JNK pathway and enhance radiation-induced apoptosis. Cancer Res, 1999; 59(10): 2457-2463.

9. Berdel WE, Bausert WR, Weltzien HU, Modolell ML, Widmann KH, Munder PG. The influence of alkyl-lysophospholipids and lysophospholipidsactivated macrophages on the development of metastasis of 3-Lewis lung carcinoma. Eur $J$ Cancer, 1980; 16(9): 1199-1204.

10. Tarnowski GS, Mountain IM, Stock CC, Munder PG, Weltzien HU, Westphal O. Effect of lysolecithin and analogs on mouse ascites tumors. Cancer Res, 1978; 38(2): 339-344.

11. Scherf HR, Schuler B, Berger MR, Schmähl D. Therapeutic activity of ET-18-OCH3 and hexadecylphosphocholine against mammary tumors in BD-VI rats. Lipids, 1987; 22(11): $927-$ 929.

12. Berdel WE, Fink U, Rastetter J. Clinical phase I pilot study of the alkyl lysophospholipid derivative ET-18-OCH3. Lipids, 1987; 22(11): 967-969.

13. Dorlo TP, Balasegaram M, Beijnen JH, de Vries PJ. Miltefosine: a review of it pharmacology and therapeutic efficacy in the treatment of leishmaniasis. J Antimicrob Chemother, 2012; 67(11): 2576-2597.

14. Breiser A, Kim D J, Fleer E A, Damenz $\mathrm{W}$, Drube A, Berger M, et al. Distribuition and metabolism of hexadecylphosphocholine in mice. Lipids, 1987; 22(11): 925-926.

15. Unger C, Damenz W, Fleer E A, Kim D J, Breiser A, Hilgard P, et al. Hexadecylphosphocholine, a new ether lipid analogue. Studies on the antineoplasic activity in vitro e in vivo. Acta Oncol, 1989; 28(2): 213217.

16. Verweij J, Gandia D, Planting AS, Stoter G, Armand JP. Phase II study of oral miltefosine in patients with squamous cell head and neck cancer. Eur J Cancer, 1993; 29A(5):778-779.

17. Crul M, Rosing H, de Klerk GJ, Dubbelman $\mathrm{R}$, Traiser M, Reichert S, et al. Phase I and pharmacological study of a daily oral administration of perifosine (d-21266) in patients with advanced solid tumors. Eur J Cancer, 2002; 38(12): 1615-1621.

18. Hilgard P, Klenner T, Stekar J, Nössner G, Kutscher B, Engel J. D-21266, a new heterocyclic alkylphospholipid with antitumour activity. Eur J Cancer, 1997; 33(3): 442-446.

19. S Vink SR, Schellens JH, van Blitterswijk WJ, Verheij M. Tumor and normal tissue pharmacokinects of perifosine, an oral anticancer alkylphospholipid. Invest New Drugs, 2005; 23(4): 279-286.

20. Berger MR, Konstantinov SM, Eibl RH. Erucylphosphocholine is the prototype of i.v. injectable alkylphosphocholines. Drugs Today, 1998; 34: 73-81.

21. Kaufmann-Kolle P, Berger MR, Unger C, Eibl H. Systemic administration of alkylphosphocholines. Erucylphosphocholine and liposomal hexadecylphosphocholine. $A d v$ Exp Med Biol, 1996; 416: 165-168.

22. Jendrossek V, Hammersen K, Erdlenbruch B, Kugler W, Krügener R, Eibl H, et al. Strutureactivity relationships of alkylphosphocholine derivatives: antineoplastic action on brain tumor cell lines in vitro. Cancer Chemother Pharmacol, 2002; 50(1): 71-79.

23. R Bagley RG, Kurtzberg L, Rouleau C, Yao M, Teicher BA. Erufosine, an alkylphosphocholine, with differential toxicity to human cancer cells and bone marrow cells. Cancer Chemother Pharmacol, 2011; 68(6): 1537-1546.

24. Fiegl M, Lindner LH, Juergens M, Eibl H, Hiddemann W, Braess J. Erufosine, a novel alkylphosphocholine, in acute myeloid leukemia: Single activity and combination with other 
antileukemic drugs. Cancer Chemother Pharmacol, 2007; 62(2): 321-329.

25. Papazafiri P, Avlonitis N, Angelou P, Calogeropoulou T, Koufaki M, Scoulica E, et al. Structure-activity relationships of antineoplastic ring-substituted ether phospholipid derivates. Cancer Chemother Pharmacol, 2005; 56(3):261-270.

26. Heerklotz H. Interactions of surfactants with lipid membranes. $Q$ Rev Biophys, 2008;41(3-4):205264.

27. Schreier S, Malheiros SV, de Paula E. Surface active drugs: self-association and interaction with membranes and surfactants. Physicochemical and biological aspects. Biochim Biophys Acta, 2000; 1508(1-2):210-234.

28. Preté PS, Gomes K, Malheiros SV, Meirelles NC, de Paula E. Solubilization of human erythrocyte membranes by non-ionic surfactants of the polyoxyethylene alkyl ethers series. Biophys Chem, 2002; 97(1):45-54.

29. Strassheim D, Shafer SH, Phelps SH, Williams CL. Small cell lung carcinoma exhibits greater phospholipase C- $ß 1$ expression and edelfosine resistance compared with non-small cell lung carcinoma. Cancer Res, 2000; 60(10): 27302736.

30. van Blitterswijk WJ, Verheij M. Anticancer alkylphospholipids: mechanisms of action, cellular sensitivity and resistance, and clinical prospects. Curr Pharm Des, 2008; 14(21): 20612074.

31. van der Luit A H, Vink S R, Klarenbeek J B, Perrissoud D, Solary E, Verheij M et al. A new class of anticancer alkylphospholipids uses lipid rafts as membrane gateways to induce apoptosis in lymphoma cells. Mol Cancer Ther, 2007; 6(8): 2337-2345.

32. Nieto-Miguel T, Fonteriz RI, Vay L, Gajate C, López-Hernández S, Mollinedo F. Endoplasmic reticulum stress in the proapoptotic action of edelfosine in solid tumor cells. Cancer Res, 2007; 67(21): 10368-10378.

33. van der Sanden MH, Meems H, Houweling M, Helms JB, Vaandrager AB. Induction of CCAAT/enhancer-binding protein (C/EBP)homologous protein/growth arrest and DNA damage-inducible protein 153 expression during inhibition of phosphatidylcholine synthesis is mediated via activation of a $\mathrm{C} / \mathrm{EBP}$-activating transcription factor-responsive element. $J$ Bio Chem, 2004; 279(50): 52007-52015.

34. Ruiter GA, Verheij M, Zerp SF, van Blitterswijk WJ. Alkyl-lysophospholipids as anti-cancer agents and enhancers of radiation-induced apoptosis. Int J Radiat Oncol Biol Phys, 2001; 49(2): 415-419.

35. Dineva IK, Zaharieva MM, Konstantinov SM, Eibl H, Berger MR. Erufosine suppresses breast cancer in vitro and in vivo for its activity on
PI3K, c-Raf and Akt proteins. J Cancer Res ClinOncol, 2012; 138(11): 1909-1917.

36. van der Luit AH, Budde M, Ruurs P, Verheij M, van Blitterswijk WJ. Alkyl-lysophospholipid accumulates in lipid rafts and induces apoptosis via raft-dependent endocytosis and inhibition of phosphatidylcholine synthesis. $J$ Biol Chem, 2002; 277(42): 39541-39547.

37. A Van Der Luit AH, Budde M, Verheij M, Van Blitterswijk WJ. Different modes of internalization of apoptotic alkyllysophospholipid and cell-rescuing lysophosphatidylcholine. Biochem J, 2003; 374(Pt 3): 747-753.

38. Marco C, Jiménez-López JM, Ríos-Marco P, Segovia JL, Carrasco MP. Hexadecylphosphocholine alters nonvesicular cholesterol traffic from the plasma membrane to the endoplasmic reticulum and inhibits the synthesis of sphingomyelin in HepG2 cells. Int $J$ Biochem Cell Biol, 2009; 41(6): 1296-1303.

39. Carrasco MP, Jiménez-López JM, Ríos-Marco P, Segovia JL, Marco C. Disruption of cellular cholesterol transport and homeostasis as a novel mechanism of action of membrane-targeted alkylphospholipid analogues. $\mathrm{Br} J$ Pharmacol, 2010; 160(2): 355-366.

40. Li Z, Tan F, Liewehr DJ, Steinberg SM, Thiele CJ. Thiele. In vitro and in vivo inhibition of neuroblastoma tumor cell growth by AKT inhibitor perifosine. J Natl Cancer Inst, 2010; 102(11): 758-770.

41. Richardson PG, Eng C, Kolesar J, Hideshima T, Anderson KC. Perifosine, an oral, anti-cancer agent and inhibitor of the Akt pathway: mechanistic actions, pharmacodynamics, pharmacokinetics, and clinical activity. Expert Opin Drug MetabToxicol, 2012; 8(5): 623-633.

42. Gills JJ, Dennis PA. Perifosine: Update on a novel Akt inhibitor. CurrOncol Rep, 2009; 11(2): 102-110.

43. Fu L, Kim Y A, Wang X, Wu X, Yue P, Lonial S et al. Perifosine inhibits mammalian target of rapamycin signaling through facilitating degradation of major components in the mTOR axis and induces autophagy. Cancer Res, 2009; 69(23): 8967-8976.

44. Alam MM, Joh EH, Park H, Kim B, Kim DH, Lee YS. Synthesis, characterization and Akt phosphorylation inhibitory activity of cyclopentanecarboxylate-substituted alkylphosphocholines. Bioorg Med Chem, 2013; 21(7): 2018-2024.

45. Kondapaka SB, Singh SS, Dasmahapatra GP, Sausville EA, Roy KK.. Perifosine, a novel alkylphospholipid, inhibits protein kinase B activation. Mol Cancer Ther, 2003; 2(11): 10931103.

46. Hennessy B T, Lu Y, Poradosu E, Yu Q, Yu S, Hall $\mathrm{H}$, et al. Pharmacodynamic markers of 
perifosine efficacy. Clin Cancer Res, 2007; 13(24): 7421-7431.

47. Kim AH, Khursigara G, Sun X, Franke TF, Chao MV. Akt phosphorylates and negatively regulates apoptosis signal-regulating kinase 1. Mol Cell Biol, 2001; 21(3): 893-901.

48. Yuan ZQ, Feldman RI, Sussman GE, Coppola D, Nicosia SV, Cheng JQ. AKT2 inhibition of cisplatin-induced $\mathrm{JNK} / \mathrm{p} 38$ and Bax activation by phosphorylation of ASK1: Implication of AKT2 in chemoresistance. $J$ Biol Chem, 2003; 278(26): 23432-23440.

49. Sun W, Modak S. Emerging treatment options for the treatment of neuroblastoma: potential role of perifosine. Onco Targets Ther, 2012; 5: 21-29.

50. Chen M B, Wu X Y, Tao G Q, Liu C Y, Chen J, Wang L Q et al.Perifosine sensitizes curcumininduced anti-colorectal cancer effects by targeting multiple signaling pathways both in vivo and in vitro. Int $J$ Cancer, 2012; 131(11): 2487-2498.

51. Wagner BA, Buettner GR, Burns CP. Increased generation of lipid-derived and ascorbate free radicals by L1210 cells exposed to the ether lipid edelfosine. Cancer Res, 1993; 53(4): 711-713.

52. Ji C, Yang Y L, Yang Z, Tu Y, Cheng L, Chen B et al.Perifosine sensitizes UVB-induced apoptosis in skin cells: New implication of skin cancer prevention? Cell Signal, 2012; 24(9): 1781-1789.

53. Ichijo H, Nishida E, Irie K, ten Dijke P, Saitoh $\mathrm{M}$, Moriguchi $\mathrm{T}$ et al. Induction of apoptosis by ASK1, a mammalian MAPKKK that activates SAPK/JNK and p38 signaling pathways. Science, 1997; 275(5296): 90-94.

54. Nagai $H$, Noguchi $T$, Takeda $K$, Ichijo $H$. Pathophysiological roles of ASK1-MAP kinase signaling pathways. J Biochem Mol Biol, 2007; 40(1): 1-6.

55. Peter ME, Krammer PH. The CD95(APO-1/Fas) DISC and beyond. Cell Death Differ, 2003; 10(1): 26-35.

56. Algeciras-Schimnich A, Shen L, Barnhart BC, Murmann AE, Burkhardt JK, Peter ME. Molecular ordering of the initial signaling events of CD95. Mol Cell Biol, 2002; 22(1): 207-220.

57. Eramo A, Sargiacomo M, Ricci-Vitiani L, Todaro M, Stassi G, Messina C G M et al. CD95 death-inducing signaling complex formation and internalization occur in lipid rafts of type I and type II cells. Eur J Immunol, 2004; 34(7): 19301940.

58. Gajate C, Mollinedo F. Edelfosine and perifosine induce selective apoptosis in multiple myeloma by recruitment of death receptors and downstream signaling molecules into lipid rafts. Blood, 2007; 109(2): 711-719.

59. Gajate C, Fonteriz R I, Cabaner C, AlvarezNoves G, Alvarez-Rodriguez Y, Modolell M et al. Intracellular triggering of Fas, independently of FasL, as a new mechanism of antitumor ether lipid-induced apoptosis. Int $J$ Cancer, 2000; 85(5): 674-682.

60. Mollinedo F, de la Iglesia-Vicente J, Gajate C, Estella-Hermoso de Mendoza A, Villa-Pulgarin J A, Campanero M A et al. Lipid raft-targeted therapy in multiple myeloma. Oncogene, 2010; 29(26): 3748-3757.

61. Geilen C C, Haase R, Buchner K, Wieder T, Hucho F, Reutter W. The phospholipid analogue, hexadecylphosphocholine, inhibits protein kinase $\mathrm{C}$ in vitro and antagonises phorbol esterstimulated cell proliferation. Eur J Cancer, 1991; 27(12): 1650-1653.

62. Landgraf K E, Malmberg N J, Falke J J. Effect of $\mathrm{PIP}_{2}$ Binding on the Membrane Docking Geometry of PKC $\alpha$ C2 Domain: An EPR Sitedirected spin-labeling and relaxation study. Biochemistry, 2008 ,47(32): 8301-8313.

63. Überall F, Oberhuber, Maly K, Zaknun J, Demuth L, Grunicke H H. Hexadecylphosphocholine inhibits inositol phosphate formation and protein kinase C activity. Cancer Res, 1991; 51(3): 807812.

64. Guerrero-Valero M, Ferrer-Orta C, Querol-Audi J, Marin-Vocente C, Fita I, Gómez-Fernández J C et al. Structural and mechanistic insights into the association of $\mathrm{PKC} \alpha-\mathrm{C} 2$ domain to $\operatorname{PtdIns}(4,5)$. PNAS, 2009; 106(16):6603-6607.

65. Shoji M, Raynor R L, Fleer E A, Eibl H, Vogler W R, Kou J F. Effects of hexadecylphosphocholine on protein kinase $\mathrm{C}$ and TPA-induced differentiation of HL60 cells. Lipid, 1991; 26(2): 145-149.

66. Chen R, Brady E, McIntyre T M. Human TMEM30a promotes uptake of antitumor and bioactive choline phospholipids into mammalian cells. J Immunol, 2011; 186(5): 3215-3225.

67. Fu D, Shi K, Wang Y. Bcl-2 plays a key role instead of mdrl in the resistance to hexadecylphosphocholine in human epidermoid tumor cell line KB. Cancer Lett, 1999; 142(2): 147-153.

68. Alderliesten M C, Klarenbeek J B, Van der Luit A H, van Lummel M, Jones D R, Zerp S et al. Phosphoinositide phosphatase SHIP-1 regulates apoptosis induced by edelfosine, Fas ligation and DNA damage in mouse lymphoma cells. Biochem J, 2011; 440(1): 127-135.

69. van Blitterswijk W J, Klarenbeek J B, van der Luit A H, Alderliesten M C, van Lummel M, Verheij M. Fas/CD95 down-regulation in lymphoma cells through acquired alkyllysophospholipid resistance: partial role of associated sphingomyelin deficiency. Biochem $\mathrm{J}$, 2009; 425(1): 225-234.

70. Herrmann D B, Neumann H A, Berdel W E, Heim M E, Fromm M, Boerner D, Bicker U et al. Phase I trial of the thioether phospholipid analogue BM 41.440 in cancer patients. Lipids 1987; 22 (11): 962-966. 
71. Giantonio B J, Derry C, McAleer C, McPhillips J J, O'Dwyer P J. Phase I and Pharmacokinetic Study of the Cytotoxic Ether Lipid Ilmofosine Administered by Weekly Two-Hour Infusion in Patients with Advanced Solid Tumors. Clinical Cancer Research 2004;10:1282-1288.

72. Winkelmann M, Ebeling K, Strohmeyer G, Hottenrott G, Mechl Z, Berges W et al. Treatment results of the thioether lipid ilmofosine in patients with malignant tumours. $J$ Cancer Res Clin Oncol 1992; 118(6):405-407.

73. Van Woolley P, Schultz C J, Rodriguez G I, Games R A, Rowe K W Jr, Dadey M L et al. A phase II trial of ilmofosine in non-small cell bronchogenic carcinoma. Invest New Drugs 1996;14(2):219-22.

74. Planting A S, Stoter G, Verweij J. Phase II study of daily oral miltefosine (hexadecylphosphocholine) in advanced colorectal cancer. Eur J Cancer, 1993; 29A(4): 518-519.

75. WHO. Technical Report Series 949: Control of the Leishmaniases. Report of a Meeting of the WHO Expert Committee on the Control of Leishmaniases, Geneva, 22-26 March 2010. Web. $\quad 7 \quad$ May 2013. http://whqlibdoc.who.int/trs/WHO_TRS_949_en g.pdf

76. Herrmann D B, Pahlke W, Opitz H G, Bicker U. In vivo antitumor activity of ilmofosine. Cancer Treat Rev, 1990; 17: 247-252.

77. Eibl H, Unger C. Hexadecylphosphocholine: a new and selective antitumor drug. Cancer Treat Rev ,1990; 17: 233-242.

78. Jakubowiak A J, Richardson P G, Zimmerman T, Alsina M, Kaufman J L, Kandarpa $\mathrm{M}$ et al. Perifosine plus lenalidomide and dexamethasone in relapsed and relapsed/refractory multiple myeloma: a Phase I Multiple Myeloma Research Consortium study. Br J Haematol, 2012; 158(4): 472-480.

79. Rübel A, Handrick R, Lindner L H, Steiger M, Eibl H, Budach W et al. The membrane targeted apoptosis modulators erucylphosphocholine and erucylphosphohomocholine increase the radiation response of human glioblastoma cell lines in vitro. Radiat Oncol, 2006. 1:6.

80. Aeterna Zantaris Inc. Aeterna Zentaris to Discontinue Phase 3 Trial in Multiple Myeloma with Perifosine Following Data Safety Monitoring Board Recommendation. 2013. http://www.aezsinc.com/en/page.php?p=60\&q=5 50 (accessed in July $5^{\text {th }}$ ).

81. Fu S, Hennessy B T, Ng C S, Ju Z, Coombes K $\mathrm{R}$, Wolf $\mathrm{J} \mathrm{K}$ et al. Perifosine plus docetaxel in patients with platinum and taxane resistant or refractory high-grade epithelial ovarian cancer. Gynecologic Oncology, 2012; 126: 47-53.

82. Cho D C, Hutson T E, Samlowski W, Sportelli P, Somer B, Richards P et al. Two Phase 2 Trials of the Novel Akt Inhibitor Perifosine in Patients
With Advanced Renal Cell Carcinoma After Progression on Vascular Endothelial Growth Factor-Targeted Therapy. Cancer 2012; 118: 6055-62.

83. Bendell J C, Nemunaitis J, Vukeja S J, Hagenstad C, Campos L T, Hermann R C et al. Randomized Placebo- controlled Phase II Trial of Perifosine Plus Capecitabine As Second- or Third-Line Therapy in Patients With Metastatic Colorectal Cancer. Journal of Clinical Oncology 2011; 29 (33): 4394-4400.

84. Ghobrial I M, Roccaro A, Hong F, Weller E, Rubin N, Leduc $\mathrm{R}$ et al. Clinical and Translational Studies of a Phase II Trial of the Novel Oral Akt Inhibitor Perifosine in Relapsed or Relapsed/Refractory Waldenstrom's Macroglobulinemia. Clin Cancer Res, 2010; 16(3): 1033-1041.

85. Unger C, Berdel W, Hanauske A R, Sundermann $\mathrm{H}$, Engel J, Mross K. First-time-in-man and pharmacokinetic study of weekly oral perifosine in patients with solid tumours. European Journal of Cancer, 2010; 46: 920-925.

86. Chee K G,Longmate J, Quinn D I, Chatta G, Pinski J, Twardowski P et al. The AKT Inhibitor Perifosine in Biochemically Recurrent Prostate Cancer: A Phase II California/Pittsburgh Cancer Consortium Trial. Clinical Genitourinary Cancer, 2007; 5(7): 433-437.

87. Marsh R W, Lima C M R, Levy D E, Mitchell E P, Rowland K M Jr, Benson A B 3rd A phase II trial of perifosine in locally advanced, unresectable, or metastatic pancreatic adenocarcinoma. Am J Clin Oncol, 2007; 30(1): 26-31.

88. Argiris A, Cohen E, Karrison T, Esparaz B, Mauer A, Ansari R et al. A Phase II Trial of Perifosine, An Oral Alkylphospholipid, In Recurrent or Metastatic Head and Neck Cancer. Cancer Biology and Therapy, 2006; 5(7): 766770.

89. Bailey H H, Mahoney M R, Ettinger D S, Maples W J, Fracasso P M, Traynor A M et al. Phase II Study of Daily Oral Perifosine in Patients With Advanced Soft Tissue Sarcoma. Cancer, 2006; 107: 2462-2467.

90. Ernst D S, Eisenhauer E, Wainman N, Davis M, Lohmann R, Baetz T et al. Phase II study of perifosine in previously untreated patients with metastatic melanoma. Investigational New Drugs, 2005; 23: 569-575.

91. Posadas EM, Gulley J, Arlen PM, Trout A, Parnes HL, Wright J, et al. A Phase II Study of Perifosine in Androgen Independent Prostate Cancer. Cancer Biology and Therapy, 2005; 4(10): 1133-1137.

92. Takai N, Ueda T, Ishii T, Kira N, Nishida M, Nasu K, et al. Erucylphosphocholine induces growth inhibition, cell cycle arrest, and apoptosis in human choriocarcinoma cells. Tumour Biol, 2011; 32(3): 569-74. 
93. Rudner J, Ruiner CE, Handrick R, Eibl HJ, Belka C, Jendrossek V. The Akt-inhibitor Erufosine induces apoptotic cell death in prostate cancer cells and increases the short term effects of ionizing radiation. Radiat Oncol, 2010 Nov 16;5:108.

94. Takai N, Ueda T, Nasu K, Narahara H. Erucylphosphocholine shows a strong antigrowth activity in human endometrial and ovarian cancer cells. Gynecol Oncol, 2008; 111(2): 336-43.

95. Kapoor V, Zaharieva MM, Das SN, Berger MR. Erufosine simultaneously induces apoptosis and autophagy by modulating the Akt-mTOR signaling pathway in oral squamous cell carcinoma. Cancer Lett, 2012; 319(1): 39-48.

96. Yosifov DY, Todorov PT, Zaharieva MM, Georgiev KD, Pilicheva BA, Konstantinov SM, et al. Erucylphospho-N,N,Ntrimethylpropylammonium (erufosine) is a potential antimyeloma drug devoid of myelotoxicity. Cancer Chemother Pharmacol, 2011; 67(1): 13-25.

97. Königs SK, Pallasch CP, Lindner LH, Schwamb $\mathrm{J}$, Schulz A, Brinker R, et al.Erufosine, a novel alkylphosphocholine, induces apoptosis in CLL through a caspase-dependent pathway. Leuk Res, 2010; 34(8): 1064-9.

98. Berger MR, Tsoneva I, Konstantinov SM, Eibl H. Induction of apoptosis by erucylphospho- $N, N, N$ trimethylammonium is associated with changes in signal molecule expressionand location. Ann $N$ Y Acad Sci, 2003; 1010: 307-10.

99. Croft SL, Neal RA, Pendergast W, Chan JH. The activity of alkyl phosphorylcholines and related derivates against Leishmania donovani. Biochem Pharmacol, 1987; 36(16): 2633-2636.

100. Paladin Labs Inc. Application for Inclusion of Miltefosine on WHO Model List of Essential Medicines. 2010. Web 4 May 2013. http://www.who.int/selection_medicines/committ ees/expert/18/applications/Miltefosine_applicatio n.pdf

101. Government of India - National Vector Borne Disease Control Programme. Guideline on Use of Miltefosine. Web. 7 May 2013. $<$ http://nvbdcp.gov.in/Doc/Guidelines\%20on $\% 20$ miltefosine.pdf $>$

102. Escobar P, Matu S, Marques C, Croft SL. Sensitivities of Leishmania species to hexadecylphosphocholine (miltefosine), ET-18$\mathrm{OH} 3$ (edelfosine) and amphotericin B. Acta Trop, 2002; 81(2): 151-157.

103. Yardley V, Croft SL, De Doncker S, Dujardin JC, Koirala S, Rijal S, et al. The sensitivity of clinical isolates of Leishmania from Peru and Nepal to miltefosine. Am J Trop Med Hyg, 2005; 73(2): 272-275.

104. Soto J, Rea J, Balderrama M, Toledo J, Soto P, Valda L, et al. Short Report: Efficacy of miltefosine for Bolivian cutaneous leishmaniasis. Am J Trop Med Hyg, 2008; 78(2): 210-211.

105. Soto J, Arana BA, Toledo J, Rizzo N, Vega JC, Diaz A, et al. Miltefosine for new world cutaneous leishmaniasis. Clin Infect Dis, 2004; 38(9): 1266-1272.

106. Sundar S, Sinha PK, Rai M, Verma DK, Nawin $\mathrm{K}$, Alam $\mathrm{S}$, et al. Comparison of short-course multidrug treatment with standard therapy for visceral leishmaniasis in India: An open-label, non-inferiority, randomised controlled trial. Lancet, 2011; 377: 477-486.

107. Varela-M RE, Villa-Pulgarin JA, Yepes E, Müller I, Modolell M, Muñoz DL, et al. In vitro and in vivo efficacy of ether lipid edelfosine against Leishmania spp. and SbV-resistant parasites. PloS Negl Trop Dis, 2012; 6(4):e1612.

108. Cabrera-Serra MG, Lorenzo-Morales J, Romero M, Valladares B, Piñero JE. In vitro activity of perifosine: a novel alkylphospholipid against the promastigote stage of Leishmania species. Parasitol Res, 2007; 100(5): 1155-1157.

109. Cabrera-Serra MG, Valladares B, Piñero JE. In vivo activity of perifosine against Leishmania amazonensis. Acta Trop, 2008; 108: 20-25.

110. Rihl M, Stoll M, Ulbricht K, Bange FC, Schmidt RE. Successful treatment of post-kala-azar dermal leishmaniasis (PKDL) in a HIV infected patient with multiple relapsing leishmaniasis from Western Europe. J Infect, 2006; 53(1): e25e27.

111. Schraner C, Hasse B, Hasse U, Baumann D, Faeh A, Burg G, et al. Successful treatment with miltefosine of disseminated cutaneous leishmaniasis in a severely immunocompromised patient infected with HIV-1. Clin Infect Dis, 2005; 40(12): e120-e124.

112. Eue I. Hexadecylphosphocholine selectively upregulates expression of intracellular adhesion molecule-1 and class I major histocompatibility complex antigen in human monocytes. $J$ Exp Ther Oncol, 2002; 2(6): 333-336.

113. Hochhuth $\mathrm{CH}$, Vehmeyer K, Eibl H, Unger C. Hexadecylphosphocholine induces interferongamma secretion and expression of GM-CSF mRNA in human mononuclear cells. Cell Immunol, 1992; 141(1): 161-168.

114. Garg R, Tremblay MJ. Miltefosine represses HIV1 replication in human dendritic cell/T-cell cocultures partially by inducing secretion of typeI interferon. Virology, 2012; 432(2): 271-276.

115. Chugh P, Bradel-Tretheway B, Monteiro-Filho CM, Planelles V, Maggirwar SB, Dewhurst S, et al. Akt inhibitors as an HIV-1 infected macrophage-specific anti-viral therapy. Retrovirology, 2008; 5: 11.

116. Fries DS, Fairlamb, AH. Antiprotozoal Agent, in Abraham DJ(ed), Burger's Medicinal Chemistry, Drug Discovery and Development. 6th ed., John Wiley \& Sons, New York, NY, pp 1033-1087, 2003. 
117. Olliaro P, Lazdins J, Guhl F. Developments in the treatment of leishmaniasis and trypanosomiasis. Expert Opion Emerg Drugs, 2002; 7(1): 61-67.

118. Croft SL, Snowdon D, Yardley V. The activities of four anticancer alkyllysophospholipids against Leishmania donovani, Trypanosoma cruzi and Trypanosoma brucei. J Antimicrob Chemother, 1996; 38(6): 1041-1047.

119. Saraiva VB, Gibaldi D, Previato JO, MendonçaPreviato L, Bozza MT, Freire-De-Lima CG, et al. Proinflammatory and cytotoxic effects of hexadecylphosphocoline (miltefosine) against drug-resistant strains of Trypanosoma cruzi. Antimicrob Agents Chemother, 2002; 46(11): 3472-3277.

120. Luna KP, Hernández IP, Rueda CM, Zorro MM, Croft SL, Escobar P. In vitro susceptibility of Trypanosoma cruzi strains from Santander, Colombia, to hexadecylphosphocholine (miltefosine), nifurtimox and benznidazole. Biomedica, 2009; 29(3): 448-455.

121. Konstantinov SM, Kaminsky R, Brun R, Berger MR, Zillmann U. Efficacy of anticancer alkylphosphocholines in Trypanosoma brucei subspecies. Acta Trop, 1997; 64: 145-154.

122. Lira R, Contreras LM, Rita RM, Urbina JA. Mechanism of action of anti-proliferative lysophospholipid analogues against the protozoan parasite Trypanosoma cruzi: Potentiation of in vitro activity by the sterol biosynthesis inhibitor ketoconazole. J Antimicrob Chemother, 2001; 47(5): 537-546.

123. Santa-Rita RM, Lira R, Barbosa HS, Urbina JA, de Castro SL. Anti-proliferative synergy of lysophospholipid analogues and ketoconazole against Trypanosoma cruzi (Kinetoplastida: Trypanosomatidae): cellular and ultrastructural analysis. J Antimicrob Chemother, 2005; 55(5): 780-784.

124. Seifert K, Duchêne M, Wernsdorfer WH, Kollaritsch H, Scheiner O, Wiedermann G, et al. Effects of miltefosine and other alkylphosphocholines on human intestinal parasite Entamoeba histolytica. Antimicrob Agents Chemother, 2001; 45(5): 1505-1510.

125. Walochnik J, Duchêne M, Seifert K, Obwaller A, Hottkowitz T, Wiedermann G, et al. Cytotoxic activities of alkylphosphocholines against clinical isolates of Acanthamoeba spp. Antimicrob Agents Chemother, 2002; 46(3): 695-701.

126. Blaha C, Duchêne M, Aspöck H, Walochnik J. In vitro activity of hexadecylphosphocholine (miltefosine) against metronidazole-resistant and -susceptible strains of Trichomonas vaginalis. $J$ Antimicrob Chemother, 2006; 57(2): 273-278.

127. Allan D, Payares G, Evans WH. The phospholipid and fatty acid composition of Schistosoma mansoni and of its purified tegumental membranes. Mol Biochem Parasitol, 1987; 23(2): 123-128.
128. Faghiri Z, Skelly P J. The role of tegumental aquaporin from the human parasitic worm, Schistosoma mansoni, in osmoregulation and drug uptake. FASEB J, 2009; 23(8): 2780-2789.

129. López-Arrieta J, Schneider L. Metrifonate for Alzheimer's disease. Cochrane Database of Syst Rev (1): CD003155 2008. doi:10.1002/ 14651858.CD003155.pub3.

130. Eissa MM, El-Azzouni MZ, Amer EI, Baddour NM. Miltefosine, a promising novel agent for schistosomiasis mansoni. Int J Parasitol, 2011; 41(2): 235-242.

131. Widmer F, Wright LC, Obando D, Handke R, Ganendren R, Ellis $\mathrm{DH}$, et al. Hexadecylphosphocholine (miltefosine) has broad-sprectum fungicidal activity and is efficacious in a mouse model of Cryptococcosis. Antimicrob Agents Chemother, 2006; 50(2): 414421.

132. Lux H, Heise N, Klenner T, Hart D, Opperdoes FR. Ether-lipid (alkyl-phospholipid) metabolism and the mechanism of action of ether-lipid analogues in Leishmania. Mol Biochem Parasitol, 2000; 111: 1-14.

133. Santangelo R, Zoellner H, Sorrell T, Wilson C, Donald C, Djordjevic J, et al. Role of extracellular phospholipases and mononuclear phagocytes in dissemination of Cryptococcosis in a murine model. Infect Immun, 2004; 72(4): 2229-2239.

134. Obando D, Widmer F, Wright LC, Sorrell TC, Jolliffe KA. Synthesis, antifungal and antimicrobial activity of alkylphospholipids. Bioorg Med Chem, 2007; 15(15): 5158-5165.

135. Lukáč M, Garajová M, Mrva M, Bukovský M, Ondriska F, Máriássy $\mathrm{E}$, et al. Relationship between aggregation properties and antimicrobial activities of alkylphosphocholines with branched alkyl chains. Int J Pharm, 2012; 423(2): 247-256.

136. Vila TV, Ishida K, de Souza W, Prousis K, Calogeropoulou T, Rozental S. Effect of alkylphospholipids on Candida albicans biofilm formation and maturation. $J$ Antimicrob Chemother, 2013; 68: 113-125.

137. Tong Z, Widmer F, Sorrell TC, Guse Z, Jolliffe $\mathrm{KA}$, Halliday $\mathrm{C}$, et al. In vitro activities of miltefosine and two novel antifungal biscationic salts against a panel of 77 dermatophytes. Antimicrob Agents Chemother, 2007; 51(6): 2219-2222.

138. Höltje JV, Tomas A. Lipoteichoic acid: a specific inhibitor of autolysin activity in pneumococcus. Proc Natl Acad Sci US A, 1975; 72(5): 16901694.

139. Le Maire M, Champeil P, Moller J V. Interaction of membrane proteins and lipids with solubilizing detergents. Biochim Biophys Acta, 2000; 1508: 86-111.

140. Llull D, Rivas L, García E. In vitro bactericidal activity of the antiprotozoal drug miltefosine against Streptococcus pneumoniae and other 
pathogenic Streptococci. Antimicrob Agents Chemother, 2007; 51(5): 1844-1848.

141. Huelves L, Del Prado G, Gracia M, RodríguezCerrato V, Ponte C. In vitro and in vivo activity of miltefosine against penicillin-sensitive and resistant Streptococcus pneumoniae strains. $J$ of Chemother, 2008; 20(4): 441-444.

142. Eibl KH, Liegl R, Kernt M, Priglinger S, Kampik A. Alkylphosphocholines as a potential pharmacologic prophylaxis for posterior capsule opacification. J Cataract Refract Surg, 2009; 35(5): 900-905.

143. Eibl KH, Wertheimer C, Kernt M, Wolf A, Kook $\mathrm{D}$, Haritoglou $\mathrm{C}$, et al. Alkylphosphocholine for intraocular lens coating. J. Cataract Refract Surg, 2013; 39: 438-445.

144. Grosman N. Effects of the ether phospholipid AMG-PC on mast cells are similar to that of the ether lipid AMG but different from that of the analogue hexadecylphosphocholine. Immunopharmacology, 1991; 22(1): 39-47.

145. Weller K, Artuc M, Jennings G, Friedrichson T, Guhl S, dos Santos RV, et al. Miltefosine inhibits human mast cell activation and mediator release both in vitro and in vivo. $J$ Invest Dermatol, 2009; 129(2): 496-498.

146. Arthur G, Bittman R. The inhibition of cell signaling pathways by antitumor ether lipids. Biochim Biophys Acta, 1998; 1390(1): 85-102.
147. Magerl M, Rother M, Bieber T, Biedermann T, Brasch J, Dominicus R, et al. Randomized, double-blind, placebo-controlled study of safety and efficacy of miltefosine in antihistamineresistant chronic spontaneous urticaria. J Eur Acad Dermatol Venereol, 2012; 27(3): e363-e369.

148. Pachioni J A, Magalhães J G, Parise-Filho R, Rangel-Yagui $\mathrm{C} \quad \mathrm{O}$ Synthesis of alkylphosphocholines potentially less hemolytic than the drug Miltefosine. Abstract book of the $6^{\text {th }}$ Brazilian Simposium on Medicinal Chemistry, $\mathrm{RS}$, Brazil; http://www.ufrgs.br/brazmedchem2012/docs/Bra zmedchem_ebook.pdf, 2012.

149. Lima E J C, Tanabe C A Y, Sá M M, RangelYagui CO (2012, October). Synthesis of cyclohexylethylphosphocholine - a novel miltefosine analogue. Abstract book of the $6^{\text {th }}$ Brazilian Simposium on Medicinal Chemistry, RS, $\quad$ Brazil; http://www.ufrgs.br/brazmedchem2012/docs/Bra zmedchem ebook.pdf, 2012.

150. Sá M M, Pasqualoto, K. F. M., Modestia, S. M., Rangel-Yagui, C. O. Alkylphosphocholines as promising antitumor agents: Exploring the role of structural features on the hemolytic potential. Mol Inf(In Press), 2013. 